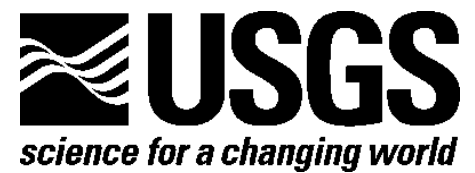

Prepared in cooperation with the NorthPlatte, South Platte, and Twin Platte Natural Resource Districts, Nebraska

\title{
Airborne Geophysical Surveys Conducted in Western Nebraska, 2010-Contractor Reports and Data
}

By U.S.Geological Survey Crustal Geophysics and Geochemistry Science Center

Open-File Report 2013-1268

U.S. Department of the Interior

U.S. Geological Survey 


\section{U.S. Department of the Interior \\ SALLY JEWELL, Secretary}

\section{U.S. Geological Survey \\ Suzette M. Kimball, Acting Director}

U.S. Geological Survey, Reston, Virginia: 2014

For more information on the USGS-the Federal source for science about the Earth, its natural and living resources, natural hazards, and the environment-visit http://www.usgs.gov or call 1-888-ASK-USGS

For an overview of USGS information products, including maps, imagery, and publications, visit http://www.usgs.gov/pubprod

To order this and other USGS information products, visit http://store.usgs.gov

Suggested citation:

U.S. Geological Survey Crustal Geophysics and Geochemistry Science Center, 2014, Airborne geophysical surveys conducted in western Nebraska, 2010—Contractor reports and data: U.S. Geological Survey Open-File Report 2013-1268, 4 p., http://dx.doi.org/10.3133/ofr20131268.

ISSN 2331-1258 (online)

Any use of trade, firm, or product names is for descriptive purposes only and does not imply endorsement by the U.S. Government.

Although this information product, for the most part, is in the public domain, it also may contain copyrighted materials as noted in the text. Permission to reproduce copyrighted items must be secured from the copyright owner. 


\section{Contents}

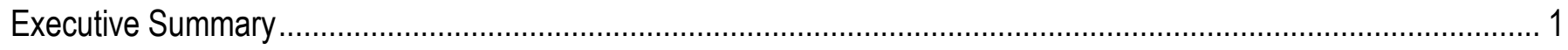

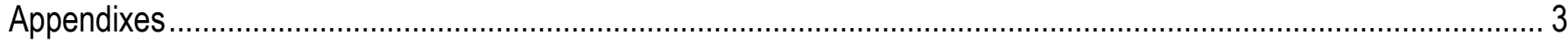

Appendix 1. Contractor Report Aarhus Geophysics/SkyTEM Canada, Inc.-Data Acquisition from Nebraska, USA

Report File: 20140203_Nebraska_Report_updated.pdf ......................................................................... 4

Data File: 20100901_DataDelivery.zip ............................................................................................ 4

Appendix 2. Contractor Reports, Aarhus Geophysics ApS-Data Processing and Inversion of SkyTEM Data, Nebraska, USA

Report File: SkyTEM USGS UTM13_complete.pdf

Report File: SkyTEM USGS UTM14_complete.pdf

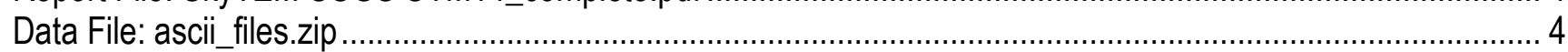

\section{Figure}

1. SkyTEM Canada, Inc., survey flight lines, western Nebraska, flown in 2010 


\title{
Airborne Geophysical Surveys Conducted in Western Nebraska, 2010-Contractor Reports and Data
}

\author{
By U.S. Geological Survey Crustal Geophysics and Geochemistry Science Center
}

\section{Executive Summary}

This report contains three contractor reports and data files for an airborne electromagnetic survey flown from June 28 to July 7, 2010. The first report; "SkyTEM Survey: Nebraska, USA, Data" describes data aquisition and processing from a time-domain electromagnetic and magnetic survey performed by SkyTEM Canada, Inc. (the North American SkyTEM subsidiary), in western Nebraska, USA, (fig. 1). Digital data for this report are given in Appendix 1. The airborne geophysical data from the SkyTEM survey subsequently were processed and inverted by Aarhus Geophysics ApS, Aarhus, Denmark, to produce resistivity depth sections along each flight line. The result of that processing is described in two reports presented in Appendix 2, "Processing and inversion of SkyTEM data from USGS Area UTM-13" and "Processing and inversion of SkyTEM data from USGS Area UTM-14."

Funding for these surveys was provided by the North Platte Natural Resources District, the South Platte Natural Resources District, and the Twin Platte Natural Resources District, in Scottsbluff, Sidney, and North Platte, Nebraska, respectively. Any additional information concerning the geophysical data may be obtained from the U.S. Geological Survey Crustal Geophysics and Geochemistry Science Center, Denver, Colorado. 


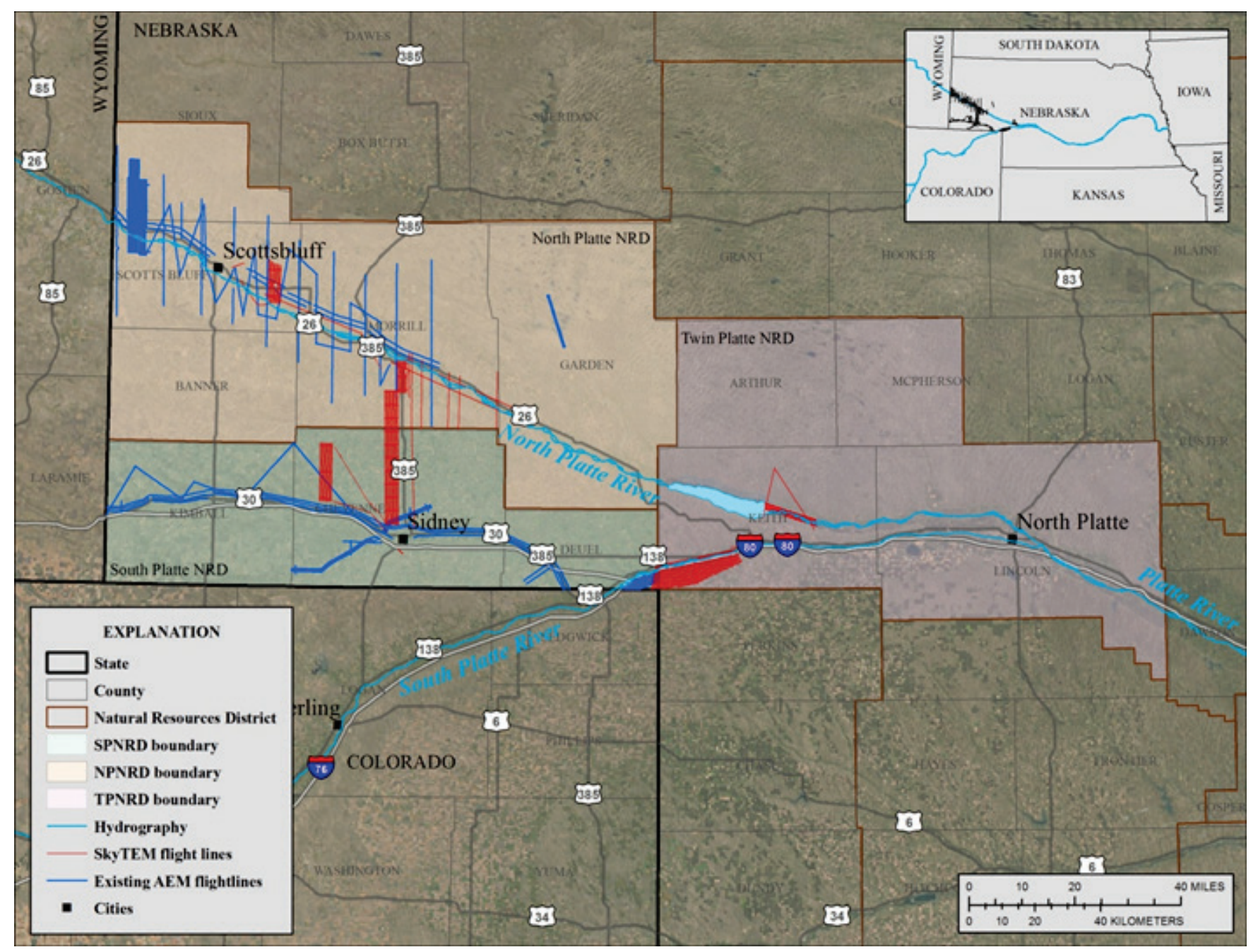

Figure 1. Location of SkyTEM Canada, Inc., geophysical survey flight lines (shown in bright red) in western Nebraska. Also shown are natural resource districts which were cooperators in the airborne electromagnetic survey. Modified from SkyTEM Canada, Inc. contractor report (see Appendix1, this publication). [Abbreviations: AEM, airborne electromagnetic survey flightlines (already existing and shown here in bright blue); NRD, Natural Resource District; NPNRD, North Platte Natural Resources District; SPNRD, South Platte Natural Resources District; TPNRD, Twin Platte Natural Resources District] 
Appendixes 


\section{Appendix 1. Contractor Report Aarhus Geophysics/SkyTEM Canada, Inc.-Data Acquisition from Nebraska, USA}

The contractor report provides details of project design and data acquisition over some $1900 \mathrm{~km}$ of flight lines in western Nebraska, including instrumentation and set-up, method(s) to synchronize data, calibration of the electromagnetic system (to accommodate differences between the North American power grid and the Danish National Reference site with its different grid frequency), and quality assurance for the data set. Protocols also describe data acquisition with detailed maps, weather reports, and base-station information. Application of the digital elevation model and data processing are discussed in detail. Location information from differential global positioning (DGPS) provided extreme accuracy and was used in data acquisition and as input to the processing flow. Residual magnetic field was the product of the processed data, from which total magnetic intensity was recalculated.

Similarly, the report presents all elements of the inversion and modeling of the Nebraska SkyTEM data. Inversion was performed as a regularized, damped, least-squares inversion along the profiles with a 1-D, 30-layer model. The inversion produced a model for approximately every $4 \mathrm{~m}$ along the flight line. Resulting models are presented as model sections (profiles) and as resistivity grids.

Data files include the following:

Report File: 20140203_Nebraska_Report_updated.pdf (note: appendixes 4, 5, and 6 of this file are given in the data delivery file listed below, and appendix 7 describes the format for delivered digital data).

Data File: 20100901_DataDelivery.zip (1.09 gigabytes).

\section{Appendix 2. Contractor Reports, Aarhus Geophysics ApS-Data Processing and Inversion of SkyTEM Data, Nebraska, USA}

Processing and Inversion of SkyTEM Data from USGS Nebraska Area UTM-13

Processing and Inversion of SkyTEM Data from USGS Nebraska Area UMT-14

This appendix contains processed data and two sets of inversions and models in two geographic areas (listed above). Two contractor reports present data (in a separate zipped file) processed and inverted by Aarhus Geophysics ApS, Aarhus, Denmark, after data acquisition from airborne timedomain electromagnetic geophysical surveys in Nebraska in 2010, located within the UTM Zone-13 and UTM Zone-14 reference meridians. Total processed line length was about $1890 \mathrm{~km}$; included maps illustrate location of the lines. Full details of the processing and the subsequent inversion appear in reports for the UTM-13 and UTM-14 areas, respectively, including flight-line locations and profiles, inversion quality-control maps, and average resistivity maps at various depth intervals. Relevant file names include:

Report File: SkyTEM USGS UTM13_complete.pdf

Report File: SkyTEM USGS UTM14_complete.pdf

Data File: ascii_files.zip [data files]

Note that data appear as ascii-format files, in a file named ascii_files.zip (approximately 74 megbytes).

Files to accompany this report are provided electronically through links from the USGS Publications Warehouse web site. (See suggested citation, this report, for full URL address.) 